\title{
MOBBING PREVENTION AS ONE OF THE CHALLENGES OF A MODERN ORGANIZATION
}

\author{
Anna GEMBALSKA-KWIECIEŃ \\ Silesian University of Technology, Faculty of Organization and Management, Institute of Economics and \\ Informatics, Zabrze; Anna.Gembalska-Kwiecien@polsl.pl, ORCID: 0000-0001-9275-0447
}

Purpose: The paper discusses a comprehensive approach to the phenomenon of mobbing within an organization. It shows its characteristics and the causes of this negative phenomenon in an enterprise. It presents the profile of both a mobber and a victim of mobbing. It outlines the course of mobbing, the tactics used in the process and its effects.

Design/methodology/approach: Literature research of the subject was carried out.

Findings: It also indicates the methods of mobbing prevention, with particular emphasis on the broadly understood prophylaxis, both on the level of organization and the employee.

Research limitations/implications: (not applicable)

Practical implications: Managerial staff should also develop (or delegate this task to HR or PR department) a program of anti-mobbing activities, taking into account the nature of the organization, improve their qualifications on the management of ethical conflicts, and promote ethical behaviour in the enterprise or institution: promote good practices, appreciate positive behaviour and strongly condemn unethical behaviour.

Social implications: Mobbing is a phenomenon that has existed for a long time, but in recent years, in countries where human rights are respected, it was decided to fight this pathology.

Originality/value: Mobbing prevention in an enterprise must be a systemic action. First and foremost, it concerns the employer, who should introduce anti-mobbing procedures and immediately react to unacceptable behaviour in the workplace. Employees can also protect themselves from mobbing.

Keywords: mobbing, human factor, work organization, mobbing prevention.

Category of the paper: General review.

\section{Introduction}

Over the past quarter of a century researchers in interpersonal relations and HR management processes in organizations have identified a special type of conflict in the workplace and called it mobbing. Mobbing has become both the subject of scientific research, as well as a trendy 
topic of current journalistic articles, and in several Western countries it is already subject to legal regulations and penalization.

Mobbing at work is a phenomenon that takes a heavy toll in our times. The purpose of such behaviour towards subordinates is often humiliation, ridiculing an employee, isolating or eliminating them from the team. Research shows that the symptoms of mobbing and generally toxic behaviour are becoming more and more frequent in organizations. The presence of psychological terror (in extreme situations, also physical) in an organization, enterprise or institution gives rise to serious costs, not only individual (loss of health, disruption of relations between employees), but also organizational (absenteeism, loss of productivity, high staff turnover) and social (participation in costs related to the end of career of the victim, earlier than planned), which translate into considerable sums. In the Polish law, the employer is obliged to prevent mobbing. If they do not, they violate the law. One of the explanations for the circumstances conducive to mobbing is the slimming and flattening of structures in companies, and thus creating greater freedom of action for people behaving in an unethical and harmful way to others (PIP, 2018). Therefore, it is important to discuss mobbing in the workplace and the possible solutions to this problem if it occurs within an enterprise. Actions aimed at eliminating or at least reducing the occurrence of violence in the workplace (mobbing is one of its components) should lie in the interest of the employee, organization and the whole society.

\section{Mobbing and its characteristics}

The term mobbing has already entered the Polish language permanently, although it happened relatively recently. In the United Kingdom the term bullying or workplace bullying is used. Currently, the terms mobbing and bullying are most often used interchangeably by experts (Kasprzyk, and Gembalska-Kwiecień, 2005; Kucharska, 2012; Gembalska-Kwiecień, 2017a).

Mobbing refers to psychological and/or physical violence used in the work environment. It is an action that has a negative impact not only on the individual or individuals that are victims, but also on the functioning of the entire organization in which it takes place.

The legal regulations on mobbing appeared in the Labour Code in 2004. In the meaning of Article 94(3) §2, mobbing is "an employee's action or behaviour concerning an employee or directed against them, consisting in persistent and prolonged harassment or intimidation of an employee, causing them to underestimate their professional suitability, resulting in or aimed to result in humiliation or ridiculing of an employee, isolating or eliminating them from the team of colleagues" (Kucharska, 2012). 
The above definition contains the necessary elements making identification of mobbing possible - i.e. the actions and behaviour concerning an employee or directed against them:

- this behaviour includes harassment and intimidation,

- it must be systematic and prolonged (mobbing is a process - it must last over a period of time),

- its goal is to humiliate or ridicule an employee, isolate or eliminate them from a team of colleagues,

- these actions cause the employee to underestimate their professional suitability, feel humiliated and ridiculed, and isolate them from the team of colleagues.

The most commonly used mobbing techniques involve:

- actions that make it impossible to speak freely (e.g. interrupting, intimidating, ridiculing, criticizing or making humiliating gestures and looks),

- actions that weaken social bonds (e.g. ignoring, prohibiting contact with other employees),

- actions that reduce the employee's reputation (e.g. ridiculing, questioning decisions, spreading gossips about an employee, suggesting a mental illness),

- actions undermining professional position (e.g. assigning too much or too little work, overburdening with duties, taking away the tasks previously assigned, ordering pointless work),

- actions that have adverse effects on physical health (e.g. assigning work that is a health hazard).

The indicators that can be helpful in diagnosing mobbing are:

- Inability to determine specific and rational reasons for this behaviour.

- Determining whether this behaviour is repetitive or prolonged and continuous.

- Are these events of a similar nature?

- Did they lower the self-esteem and deteriorate health condition?

As stated earlier, mobbing must be a persistent and long-lasting process - similar situations have to be repeated many times, systematically, for a long time. One-off and incidental situations cannot be considered as mobbing.

Mobbing may be (Kusy et al., 2009):

- vertical (oblique): when the mobber and the victim are at various levels in the employment hierarchy, most often in the relations between the employer and the employee,

- horizontal (simple): there is no subordination, in the employment structure they are on the same level (employee - employee).

In a company, the employer is obliged to undertake anti-mobbing activities. Their tasks include prevention of psychological violence in the workplace and supporting the victim by eliminating mobbing occurrence in the work environment. 
This activity may involve the development of principles of mobbing prevention defining, clearly and unambiguously, the principles of employee subordination, their competences and scope of duties, methods of decision-making and resolving possible conflicts, and the principles of information flow (the work regulations or the company collective agreement may be used for this purpose). After receiving the employee's complaint, the employer should immediately create an anti-mobbing committee that will investigate whether the complaint is justified. The committee should be impartial, so its members should include representatives of the employer and employees, it can be supplemented with a third party, jointly designated by the employer and employees. However, it must be properly trained in terms of substance and demonstrate the ability to resolve conflicts. The committee's task is to analyse the allegations and evidence contained in the complaint, hear the parties, explain the cause of the problem and decide whether the complaint is justified and how the perpetrator will be punished. The above proceedings are confidential.

If the employee has suffered a health disorder (certified by medical opinion) as a result of the mobbing, they may assert, by an action brought before the labour court, an appropriate sum as financial compensation for the non-material damage they suffered under Article 94(3) § 3; if, however, due to mobbing, they terminated the employment contract, they have the right to claim compensation from the employer in an amount not lower than the minimum salary under Article 94(3) § 4. It should be noted that the employee's declaration on termination of the employment contract (both with respect to the notice period, with and without the employer's fault, pursuant to Article 55 of the Labour Code) must be made in writing and contain justification indicating specific actions and behaviour towards the employee which, in their opinion, should be classified as mobbing. It should be noted that stating whether specific activity or behaviour is a form of mobbing is a contentious issue, which, pursuant to Article 262 of the Labour Code, only a labour court can settle. In the course of court proceedings, the employee must prove that mobbing practices have been applied against them - the burden of proof lies with them. In court practice, evidence from witnesses has the highest value in such cases (Chakowski, 2012).

\section{The causes of mobbing within an enterprise}

The main causes of mobbing in a company are conflicts, management mistakes and inadequate organizational structure. Another significant cause of the occurrence of mobbing is also the lack of clear and transparent principles of the organization's functioning, defining the values that employees should be guided by, as well as the desirable and unacceptable types of behaviour. The key reasons for mobbing mentioned above, which may result in pathological behaviour in the workplace, are combined with individual factors. 
As the literature on the subject indicates, the characteristics of people who become victims and perpetrators of mobbing are an important individual factor. Of course, one cannot talk about specific predisposition towards being a mobber or a victim. However, it is useful to know individual features that affect specific behaviours manifested by the mobber and victim of mobbing. People who exert violence on others tend to display a toxic personality and draw their strength from the system in which they are functioning. Usually, not only one person is guilty, but the whole system that supports this phenomenon is responsible. Organizational costs are usually big, because a "sick" individual infects others around them.

However, one should be aware that mobbing will not occur in an organization in which the employer absolutely does not accept this phenomenon, even if their employees have the characteristics typical of a mobber. The following mistakes are conducive to mobbing in an enterprise.

Superior's mistakes in treating subordinates:

- underestimating employees and the results of their work,

- distrust of subordinates,

- excessive control of work,

- insulating the work environment,

- limiting employee contacts with the environment,

- lack of proper communication in the enterprise,

- not discussing the problems occurring in the team with subordinates,

- authoritarian power,

- strongly visible division into superior and subordinates.

Mistakes of the team of employees (Kucharska, 2012):

- the need to find the so-called "scapegoats" - persons responsible for all organizational faults,

- lack of sense of responsibility for individual employee duties,

- lack of trust between employees,

- creating a network of hearsay and rumours in the enterprise,

- excluding new employees from the circle of colleagues,

- constant dissatisfaction with work and its various aspects,

- lack of commitment to work and no willingness to change it. 


\section{Mobber, victim of mobbing and the course of mobbing}

Both among the people who are perpetrators and victims of mobbing are people from different backgrounds, of different age, with different education, social status, material status, etc.

Characteristics of a mobber (Kucharska, 2012; Marciniak, 2012; OSA, 2019):

- a person with an exaggerated self-esteem, overestimating their skills and competences, unable to cope with the criticism of others, to which they react with harassment,

- a person with a significantly low self-esteem - through mobbing behaviour, harassment, finding faults in other people, usually weaker, they raise their own self-esteem; they have a need to constantly increase their self-esteem, which they do at the expense of other people,

- a person with a high level of passive aggression, suppressing negative emotions, demonstrating them in a vague, camouflaged way, not directly, e.g. ambiguous comments, forgetting about things important to others,

- a person who takes care mainly about their own benefits, who perceives their colleagues as an obstacle, a threat in achieving their goals, focused on competition and not on cooperation, ready to do a lot to achieve their own benefits, even at the cost of others; jealous of other people's success, ready to destroy someone even because of their slightest success,

- a person with a very strong need for control and power,

- a person with a strong need for stimulation, bored with a monotonous work environment - in order to diversify monotony, they inflict pain and suffering on other people,

- a person who has no sense of security and is characterized by a high level of anxiety, which is reduced by them by causing anxiety of other people and threatening them; they are also characterized by cowardice and uncertainty about their reputation,

- an unskilled person, aware of their low level of competences - they live with a sense of threat that this may be revealed and may result in dismissal; therefore, they choose to reveal the incompetence and lack of knowledge of others,

- a person with a high level of aggression, very often impulsive, explosive, often acts first and thinks later, they have no reflection on their behaviour,

- a person discriminating easily, not accepting people with other beliefs, traits, convinced that a group is only effective when it is unified,

- a sadistic person, who derives great pleasure in causing pain and suffering to other people, who manipulates others, uses and hurts other people without scruple, with no remorse; who does not care about the feelings and emotions of other people having elements of the psychopathic personality, 
- a perfectionist person, who considers themselves to be infallible, treats other people like objects, focused on themselves and expects the same of others,

- an overly cordial person who is unpredictable, unnatural in showing emotions, charming and apologetic, who likes to spark compassion, infantile, seemingly harmless,

- a person who quickly and easily establishes contact with the environment, often physically, interpersonally, socially attractive, enjoying the sympathy and trust of others, which they gained by mobbing weaker people and inspiring their colleagues to violence,

- a person who draws satisfaction from the manifestation of aversion and antipathy towards a specific person, who wants others to see it, arouses and emphasizes antagonisms.

The benefits that a mobber derives from persecuting others:

- they create their image as a responsible person, focus the attention of the team on themselves, satisfy their strong need to be in the spotlight,

- they eliminate from the group of employees the persons they do not like, who often in their opinion - threaten their position,

- they satisfy their need for revenge for their failures, e.g. in family life, they eliminate negative emotions,

- they draw satisfaction from full control over both the employee and the environment and gain a sense of impunity.

Characteristics of a victim of mobbing (OSA, 2019):

- a person who is often an informal authority, standing out from the team, helpful, kind, enjoying respect and recognition of other employees,

- a person who values frankness, truthfulness, honesty,

- a conscientious, hard-working person, who does their job well, often a role model for other employees in the team,

- a highly qualified person, competent, with knowledge of foreign languages, the first to ask for advice on a given matter, who is a threat above all to employees who are unwilling to develop professionally,

- a creative person, showing initiative, likely to achieve success in the company,

- a young person who is often a threat to older employees, who try to undermine their professional experience as an argument for their insufficient skills,

- a person in a pre-retirement age, who diligently performs their duties, but does not fit the young team; they can become victims of harassment, humiliation, intended to make them resign from work,

- a sensitive person, often a little naive, allowing others to manipulate them, unsuspecting that other people's behaviour may be tricky, 
- a person clearly expressing their opinions and beliefs, even if they are unpopular and meet with reluctance of other people,

- a person defending their colleagues, often willing to sacrifice themselves in the fight for others,

- a person reacting to non-compliance with the Labour Code regulations, often not belonging to any formal grouping, such as trade unions, or informal group, such as people spending breaks together; a person who is not a member of any particular group of employees; often an individualist,

- a person different from other employees in terms of: age, convictions, dress style, tattoos, level of commitment to work, often perceived as different from the rest of the group,

- a reserved person, quiet, often helpless in life, unable to defend themselves, experiencing harassment or humiliation on their own,

- a person who cannot cope with the requirements imposed on them and is not able to perform their duties diligently,

- a person with a difficult personal and family situation, who has experienced personal failures, trouble, illness - this is why they are more susceptible to being hurt.

The features that have been outlined above, regarding both the mobber and their victim, should be treated as suggestions, hints for employers and employees, on who may be more vulnerable to mobbing and who may become perpetrators.

\section{The course of mobbing and mobbing behaviour}

Mobbing is a phenomenon of a dynamic nature, occurring for a certain period in a continuous and consistent manner.

There is no specific pattern for mobbing, because it can take different forms. However, you can see some regularities that often take place in mobbing situations.

The course of mobbing divided into phases is shown below.

In the first phase, the first incident occurs, an event in which the mobber uses mobbing behaviour such as harassment, persecution or bullying. Initially, the victim is surprised by such behaviour, does not understand the situation with which they are faced. The victim tries to explain the situation, but the persecutor does not acknowledge such a need - they see no conflict, they adopt an attitude of kindness towards the victim. The mobber tries to make the victim relax their vigilance and continues harassment alternately with an attitude of courtesy and politeness. The mobber's behaviour worries the victim, who cannot understand what is going on - kindness on the one hand, and hostility on the other. 
The second phase takes place when the mobbing behaviour gains strength, especially in the situations without witnesses, they are used in the form of passive aggression through the use of legal means, orders and official instructions. The victim tries to clarify the ambiguities, but is still told that nothing bad is happening. At the same time, behind their back, a network of rumours, hearsay and slanders about the victim is created. Their skills, competences and qualifications for the job, position etc. are undermined. As a result, the victim is slowly but systematically alienated from the group of colleagues. At the same time, because of the misunderstanding of the whole situation and the frustration resulting from the inability to resolve it, the victim has occasional outbursts of anger, cries because of their powerlessness, raises their voice, screams - these behaviours convince others that something indeed is wrong with them, and the mobber is right. In this way, the mobber wins over their colleagues, gets their support, creates a coalition against their victim. Co-workers unknowingly become the accomplices in mobbing and the victim loses their support.

In the third phase, the victim begins to realize that the situation in the enterprise is changing. Interpersonal contacts are disturbed, people move away from them, except for those with whom they are in close relationships outside work. They do not talk to them, even with regard to professional matters - they eliminate and alienate the victim from the group of employees. The victim's work performance deteriorates because psychological tension prevents them from working effectively. Harassment continues, but more people with whom the victim cooperates are the perpetrators. Gossip and slander become prevalent.

The victim begins to experience various psychosomatic ailments, the level of stress becomes so high that they are unable to work effectively. Unsatisfactory work performance begins to cause the reaction of the leadership, and reprimands begin. The grounds for comments, reprimands and even termination of the employment contract begin to emerge. The victim begins to think that what happened to them is their fault, that they deserve to be treated like that, that they are ill-adjusted, etc. Increasing health problems force them to take a sick leave more and more often.

In the fourth and last phase, the victim is unable to do their job, resigns or is dismissed because they neglect their job duties. They often find it problematic to take up another job, enter a new employee team, establish healthy relations.

The tactics frequently used in mobbing include: humiliation (defamation, ridiculing, malicious rumours), intimidation (verbal threats, telephone terror, shouting), and underestimating competences (contradictory commands, time pressure, isolation).

H. Leymann - a Swedish doctor and psychologist - has developed a list of behaviours that are considered as mobbing. Based on his research, he has identified as many as forty-five forms of mobbing behaviours, which he divided into five groups. 
According to Leymann, it is enough to experience one of the forms of behaviour listed below to talk about mobbing (Kucharska, 2012):

1. Actions hindering communication: limiting the possibility of speaking by the superior, frequent interruptions, limiting the possibility of speaking by the colleagues, reacting to comments in raised voice, insulting and cursing, constantly criticizing work, constantly criticizing private life, harassing by phone.

2. Actions disturbing social relations: avoiding conversations with the victim by the superior, not allowing the victim to speak, moving the victim to a place away from colleagues in the room where they work, forbidding colleagues to talk to the victim, ignoring.

3. Actions aimed at disrupting the social reception of a person: speaking badly behind that person's back, spreading rumours, trying to ridicule, suggesting a mental illness, referring to a psychiatric examination, mocking disability, parodying the way of walking, speaking or gestures to ridicule a person.

4. Actions affecting the quality of personal and professional life: not giving the victim any tasks, taking away the tasks given previously to perform, ordering pointless work, giving tasks below skills, assigning new tasks continuously, ordering to perform tasks offensive to the victim, assigning tasks beyond the victim's abilities and competences in order to discredit them.

5. Actions that have harmful impact on the victim's health: forcing to perform work harmful to health, threatening with physical violence, exercising slight physical violence, physical abuse, contributing to increasing costs to harm the victim, causing psychological damage in the victim's place of residence or place of work.

\section{Individual, organizational and social consequences of mobbing}

Mobbing has a negative impact on the organization, its employees and the victim itself.

On an individual level, violence in the workplace has a detrimental effect on the health of the persecuted person. Health effects may include: digestive problems, cardiovascular diseases, chronic migraine headaches, insomnia, alcohol abuse, use of sedatives and sleeping pills. In the psychological sphere they can manifest themselves through: anxiety-depressive states, anxiety, apathy, sadness, anger or excessive aggression, a decrease in self-esteem and a loss of the sense of one's own competence and professional qualifications.

Mobbing can even lead to Post-Traumatic Stress Disorder (PTSD), an illness distinguished in the Psychiatry Diagnostic Manual of the American Psychiatric Association and by the World Health Organization, that leads to permanent exclusion from the labour market. 
On the level of the organization, mobbing creates an unfriendly atmosphere in the work environment, causes deterioration of interpersonal relations and decreases work motivation. It has a direct impact on the performance, competitiveness and development of the organization. Enterprises and institutions that do not eliminate mobbing on time must reckon with sick absence (frequent, several-day sick leave is characteristic of an emotionally abused person), high staff rotation (which entails the training of new employees, recruitment costs), reduced efficiency, mistakes, negligence or accidents at work involving people who are mobbed, whose motivation was reduced and who were eliminated from the team, as well as a crisis and loss of prestige, when a mobbing scandal is publicized outside the organization by the media.

On a social level, emotional abuse means high costs of treatment, rehabilitation and social benefits related to the payment of disability or early retirement benefit to a person who has been the victim of mobbing. According to Bożena Kłos (2002), in Sweden it was estimated that $20 \%-40 \%$ of decisions to go on early retirement in the year in which the research was conducted were caused by bad relations in the work environment, and three out of five early retirees experienced mobbing.

Of course, the consequences of mobbing for the victim and their surroundings may take different forms; the examples of the most frequent consequences are listed above (Kucharska, 2012; Gembalska-Kwiecień, 2017b). Bearing in mind the mentioned consequences of mobbing, it is in the interest of the individual, organization and society to strive to eliminate emotional abuse in the workplace.

\section{Prevention of mobbing within an organization}

Combating mobbing in an organization should be handled on two levels concurrently. It is necessary to ensure proper HR management, appropriate recruitment policy, but also to focus on regular training and conferences devoted to issues connected with abuse at work. Building the organizational culture, we may not forget that it must be characterized by openness and transparency, and every employee has the right to express criticism and speak freely.

Mobbing prevention in an enterprise must be a systemic action. First and foremost, it concerns the employer, who should introduce anti-mobbing procedures and immediately react to unacceptable behaviour in the workplace. Employees can also protect themselves from mobbing.

In the prophylaxis of mobbing on the employee level, the basis of prevention is knowledge. It's important to disseminate information about: the forms of mobbing, its causes, effects and possible ways of dealing with this negative phenomenon. The knowledge of other people about the phenomenon should also be broadened - including superiors, co-workers, subordinates; they should be shown which types of behaviour they experience are allowed and which are not. 
It is also advisable to turn to professionals in this regard - read articles, search for information in anti-mobbing associations, and take advantage of training conducted by specialists in the field of mobbing. Such trainings should also be organized in your company. All these activities will facilitate reaction to cases of mobbing at its early stage and will not allow its development within the organization.

An important element of mobbing prevention is to react to any behaviour that is unacceptable. It is also necessary to prevent conflicts that arise in the enterprise. Of course, not every conflict turns into mobbing, but caution should be exercised in such situations.

As shown by the course of mobbing, it is difficult to say, at the early stage, whether you are a victim or it's just your impression or assumption. This is often because the mobber is polite, kind and courteous to their victim. Therefore, if there is a questionable behaviour, vigilance should increase (Aburumman et al., 2019; Erdal et al., 2018).

When the first mobbing behaviour appears, it should be discussed with co-workers, superiors, people outside work. Silence is the worst for the victim and the best for the mobber, because it gives the mobber the opportunity to act on the principles they set. The more people know about mobbing behaviour, the more likely it is to stop.

It is important to find among co-workers at least one person who will be an ally, preferably an employee with authority, position in the company that others will look up to.

In mobbing, the bigger the support, the better for the victim. In the situation of experiencing mobbing, it is very important to collect all evidence - record the details of mobbing events including the exact date, place, course, duration, presence of possible witnesses. The more details, the more reliable it is for the court, if the victim decides to fight for their rights and dignity in court.

It is also advisable to learn to react to verbal abuse of persecutors, and assertive attitude may be very helpful to react appropriately.

Assertiveness is the ability to express your feelings, emotions and opinions honestly; it gives you the opportunity to defend your rights while respecting the rights of other people. Assertiveness is also the ability to set boundaries, say no, and defend your views in a factual and concrete way, based on facts and not on opinions. It manifests itself in both the body language and the verbal sphere. Assertive people react in situations when they feel that their rights are broken, their boundaries are violated, that they are hurt or insulted. They show that such behaviour is unacceptable to them and they do not want it. An assertive reaction to criticism may discourage the mobber from further negative behaviour towards their victim. It shows that the person attacked will defend their rights and not allow anyone to insult them (Marciniak, 2012; Kucharska, 2012). 


\section{Final conclusions}

The problem of mobbing, identifying its forms, unmasking the methods of action, recognizing the causes of the phenomenon, revealing its consequences and mobbing prevention have a great social significance. Mobbing is a phenomenon that has existed for a long time, but in recent years, in countries where human rights are respected, it was decided to fight this pathology. International organizations considered mobbing as one of the professional risk factors, along with the risk connected to the physical working environment, such as pollination, noise and other factors that threaten the health of an employee (Reiman et al., 2019; Vierendeels et al., 2018).

A catalogue of features of organizations in which mobbing does not occur has been created; these are organizations in which, among others, there is a transparent and clearly defined division of competences and tasks, precisely defined employee evaluation system, the systems and rules of remuneration are clear and fair, the promotion system is clearly defined, there is a free flow of information, employees know decision-making methods and principles, are treated subjectively, and their opinions and ideas are taken into account by managerial staff; the managers respect human dignity, managerial staff has impeccable manners, proper recruitment and selection procedures are employed, employees are given the opportunity to develop, they are encouraged to acquire knowledge and raise qualifications, people dealing with HR management are highly qualified in this field, and managers have extensive knowledge of conflict and change management within an organization (Bechowska-Gebhardt, and Stalewski, 2004).

Managerial staff should also develop (or delegate this task to HR or PR department) a program of anti-mobbing activities, taking into account the nature of the organization, improve their qualifications on the management of ethical conflicts, and promote ethical behaviour in the enterprise or institution: promote good practices, appreciate positive behaviour and strongly condemn unethical behaviour. They should consider, within the framework of active managerial and professional education, conducting periodic ethical sensitivity training in the organization, in which both positive and negative case studies would be discussed (Maciąg, 2002). 


\section{References}

1. Aburumman, M., Newman, S., and Fildes, B. (2019). Evaluating the effectiveness of workplace interventions in improving safety culture: A systematic review. Safety Science, 118, 376-392.

2. Bechowska-Gebhardt, A., and Stalewski, T. (2004). Mobbing. Patologia zarzadzania personelem. Warszawa: Wydawnictwo Difin.

3. Chakowski, M. (2012). Mobbing aspekty prawno-organizacyjne. Bydgoszcz: Oficyna Wydawnicza Branta.

4. Chappell, D., and Di Martino, V. (2000). Violence at Work. Geneva: International Labour Organization.

5. Coyne, I., Seigne, E., and Randall, P. (2000). Predicting workplace victim status from personality. European Journal of Work and Organisational Psychology, 9, 335-349.

6. Erdal, M., Isik, N.S., and Firat, S. (2018). Evaluation of occupational safety culture in construction sector in the context of sustainability. Lecture Notes in Civil Engineering, $1,245-254$.

7. Gembalska-Kwiecień, A. (2017a). Czynnik ludzki w zarządzaniu bezpieczeństwem pracy w przedsiębiorstwie. Wybrane zagadnienia. Gliwice: Wydawnictwo Politechniki Śląskiej.

8. Gembalska-Kwiecień, A. (2017b). Fundamentals of an effective corporate safety culture. Ekonomia i Prawo, 4, 401-411.

9. Hoel, H., and Salin, D. (2003). Organisational antecedents of workplace bullying. In: S. Einarsen, H. Hoel, D. Zapf and C.L. Cooper (Eds.), Bullying and emotional abuse in the workplace. International perspectives in research and practice (pp. 203-218). LondonNew York: Taylor and Francis.

10. Kasprzyk, J., and Gembalska-Kwiecień, A. (2005). Mobbing w szkole - zjawisko zagrażajace poczuciu bezpieczeństwa. Paper session presented at I Studencka Sesja Kół Naukowych Wydziału Organizacji i Zarządzania, Zabrze.

11. Kłos, B. (2002). Mobbing. Warszawa: Kancelaria Sejmu. Biuro Studiów i Ekspertyz, Wydział Analiz Ekonomicznych i Społecznych.

12. Kucharska, A. (2012). Mobbing - informator dla pracownika. Warszawa: Główny Inspektorat Pracy.

13. Kusy, M., and Holloway, E. (2009). Toxic Workplace! Managing Toxic Personalities and Their System of Power. San Francisco: Jossey-Bass.

14. Maciąg, Z. (2002). Etyka w zarządzaniu organizacją. In: J. Dietl, and W. Gasparski (Eds.). Etyka biznesu (pp. 217-229). Warszawa: PWN.

15. Marciniak, J. (2012). Mobbing, dyskryminacja, molestowanie - zasady przeciwdziałania. Warszawa: Wolters Kluwer Polska. 
16. O’Moore, M. (2000). Bullying at Work in Ireland: A National Study. Dublin: Anti Bullying Centre.

17. Ogólnopolskie Stowarzyszenie Antymobbingowe we Wrocławiu (OSA). Available online http://www.mobbing.most.org.pl, 22.08.2016.

18. Reiman, A., Pedersen, L.M., Väyrynen, S., Sormunen, E., Airaksinen, O., Haapasalo, H.A, and Räsänen, T. (2019). Safety Training Parks - Cooperative Contribution to Safety and Health Trainings. International Journal of Construction Education and Research, $1,19-41$.

19. Standing, H., and Nicolini, D. (1997). Review of workplace-related violence. London: HSMO.

20. Ustawa z dnia 14 listopada 2003 r. o zmianie ustawy - Kodeks pracy oraz o zmianie niektórych innych ustaw. Dz.U. nr 213, poz. 2081; Art. 94³. § 2 (2003).

21. Vierendeels, G., Reniers, G., van Nunen, K., and Ponnet, K. (2018). An integrative conceptual framework for safety culture: The Egg Aggregated Model (TEAM) of safety culture. Safety Science, 103, 323-339.

22. Państwowa Inspekcja Pracy (PIP). Mobbing. Retrieved from www.pip.gov.pl/html/pl/ wydawn/pdf/mobbing.pdf, 22.08.2018. 